5 Vincent Roy, B.Eng., M.Sc.A., ASCE student member, Ph.D. Candidate, Construction Engineering

6 Department, École de technologie supérieure, Université du Québec, Montreal, Quebec (corresponding

7 author)

8 Dominique Desjardins, Bachelor's in business administration, Compliance officer, Integrity Department,

9 SNC-Lavalin, Montreal, Quebec

10 Camille Fertel, Ph.D., Lecturer at Université Sherbrooke and Economist at Tecnea Canada, Montreal,

11 Quebec

12 Claudiane Ouellet-Plamondon, P.Eng., M.Sc., Ph.D., ASCE member, Associate Professor, Construction

13 Engineering Department, École de technologie supérieure, Université du Québec, Montreal, Quebec

14 (corresponding author)

\title{
Abstract
}

16 This reflection aims to investigate the integrity-related risks for companies engaging with

17 third parties in the construction and civil engineering industry. The business partner

18 compliance process of a multinational construction engineering company is assessed

19 through internal interviews with integrity officers per business sector and per region in a

20 static and dynamic strategy framework. The actual process is the internal evaluation of a

21 ready-made tool bought from a service supplier that assess how the risks related to

22 corruption are covered in order to determine the level of due diligence necessary when 
23 engaging with a specific third party. This study finds that companies must involve their

24 own experts to improve integrity tools. Collecting expert opinions on risk is necessary to

25 allow an improved understanding of the scope of the tool. This study reflects on new ways

26 for improving the integrity tool and demonstrates the necessity to cover risks not solely

27 associated with Corruption \& Bribery, but also with Human Rights, Conflict of Interest,

28 Antitrust \& Competition, as well as Compliance with Regulations to fully protect

29 company's integrity.

30 KEYWORDS: Integrity, Construction engineering, Third party, Risk management, SWOT

31 analysis, Contrast Analysis

33 Corporate Social Responsibility (CSR) is an important corporate function in engineering 34 and construction. In addition to its direct positive impacts for a company, CSR is now 35 required by many public and private organizations (Dainty 2009). Construction 36 engineering is considered as one of the most corrupt sectors in wealthy countries (Matthews 37 2016; Transparency International 2011). New risks associated with integrity, business 38 ethics and compliance are emerging, and companies need to manage them. These risks are 39 both internal and external, and are often related to interactions between suppliers, business 40 partners, and other third parties. Of specific concern to the engineering and construction 41 industries are the very high number of daily interactions associated with the activities of 42 these stakeholders. According to the Organization for Economic Cooperation and 43 Development (OECD), three out of four foreign bribery cases involve payments through 44 intermediaries (OECD 2014a). In this context, third-party risk management theories and 
45 guidelines have emerged (Dow Jones 2018; NAVEX Gobal 2018; PACI 2013; Shen et al.

46 2018) suggesting due diligence measures as a necessary step, not only for financial

47 purposes, but also for preserving integrity. Recent events such as the Odebrecht scandal

48 reveal the importance of addressing such issues (Gallas 2019). In this context, a number of

49 research questions arise. With a high number of third parties and integrity-related risks,

50 how can construction engineering companies investigate and assess their business partners

51 thoroughly? Do generic prescriptive tools enable the protection of company's integrity?

52 Business's integrity is closely related to their code of conduct, and includes risks associated

53 with elements such as Corruption \& Bribery, Human Rights, Conflict of Interest,

54 Compliance with Regulations, and so on. Interestingly, past studies about construction risk

55 management did not integrate integrity-related risks (Deng et al. 2014; Tang et al. 2007).

56 Recent research suggests including these risks and proceeding with an overall review of

57 the entire company governance structure to cover all integrity-related risks (Mhetre 2016;

58 Sadgrove 2015). The target of this reflection is to demonstrate how companies can detect

59 flaws in their third-party management processes and what can be done to improve it

60 according to their context and reality.

61 There is a demand for prescriptive models dealing with ethical issues among construction-

62 related organizations (Ho 2011). If the company faces allegations of misconduct due to the

63 actions of a third party it has engaged, demonstrating sufficient due diligence will

64 significantly reduce any potential penalties it may face (United States Sentencing

65 Commission 2018). Moreover, many international funding institutions, such as the World

66 Bank, have strict requirements regarding due diligence measures, and risk assessment has

67 become a contractual requirement. 
68 Enterprise performance management enables continuous improvement with the help of 69 performance analysis tools (Cokins 2013). Strengths, Weaknesses, Opportunities and

70 Threats (SWOT) analysis is a static strategic framework that has been used in studies

71 examining strategic management in construction and engineering companies to evaluate

72 the management effectiveness (Zavadskas et al. 2011), to manage water resources (Rao et

73 al. 2018), and more (Bull et al. 2016; Jaber et al. 2015; Njoh 2017). The present study

74 similarly uses SWOT with internal interviews and a dynamic based strategy (Ghemawat

75 2016) to collect expert perception since the method can be easily adapted and includes

76 external and internal context for a better understanding of the company's reality. The

77 constraint approach is then applied to turn the company's weakness into advantages

78 (Brandenburger 2019).

79 To create a risk management program, one must collect data about risk perception among

80 experts. The lack of available data in the scientific literature and the dearth of prior studies

81 on this subject make it necessary to start from a company case study and then develop a

82 theory based on the findings. As part of the present research, a company operating in the

83 engineering and construction industry is analyzed. This company was chosen because of

84 its size and international renown. Following past misconduct, the company became a leader

85 in developing an ethical and integrity culture (Hachey 2012; World Bank 2013), in addition

86 to also being an innovation-driven organization systematically engaging in risk assessment.

87 2. Literature Review

88 To attain the objectives of this research, it is necessary to cover different subjects in the

89 literature to have a comprehensive understanding of the context. Firstly, the concept of 
90 integrity, its management and the unicity of the construction engineering sector is

91 discussed. Secondly, the different types of business partners are presented. Thirdly,

92 engineering risk management is shortly addressed. Fourthly, integrity-related risks and

93 their indicators according to various references are covered. Finally, enterprise

94 performance management and the use of SWOT is explained.

$95 \quad$ 2.1. Integrity

96 Integrity has many definitions. A research presenting the results of interviews with seven

97 chief executives of large firms suggests that integrity is the coherence with core values

98 such as honesty and justice (Badaracco and Ellsworth 1991). Others from the business

99 ethics area argue that integrity is being consistent with laws and regulations, and

100 demonstrating exemplary moral behavior in accordance with norms and values (Brenkert

101 2004). While defining integrity is not the core subject of this article, it is important to

102 understand that the concept of integrity is not universal. Notwithstanding this, all consider

103 that integrity engenders commitment and trust, and ensures the welfare of all stakeholders

104 (Lawton and Páez 2015).

105 Implementing corporate ethical culture is challenging. Codes of ethics are an effective way 106 to shape integrity management, but they must be embraced by the leaders and proper 107 communication is a crucial success factor (Stevens 2008). Values and ideals must be 108 discussed between the employees and management. Based on insights from strategic 109 planning, an author identified three barriers/enablers for effective governance of corporate 110 ethics (Bonn and Fisher 2005). Companies must foster a flexible approach by including 111 discussion and debates among all employees. They must also monitor the implementation 112 of ethical culture indicators that are not solely financial. Finally, companies must integrate 
113 ethics throughout the organization with training, communication channels and enthusiasm

114 from top to bottom.

115 Construction engineering is considered to be one of the most corrupt sectors (Matthews

116 2016; Transparency International 2011). What makes integrity management in the

117 construction engineering industry so special? Firstly, construction represents an important

118 part of the country's GDP and is a key driver for economic growth (Ho 2011). Secondly,

119 construction requires many interactions with governments and state employees (public

120 projects, licences, permits, etc.). Thirdly, construction companies are often working abroad

121 in developing countries where laws, regulations and ethical standards are lower (Ameyaw

122 et al. 2017). Fourthly, due to project unicity, construction engineering companies have

123 numerous business partners helping them achieve their goals. Despite efforts to produce

124 codes of ethics and conduct, it has been discussed that construction engineering industry is

125 ineffective for its implementation and that there is a lack of training and understanding

126 (Oladinrin and Ho 2016). Managing integrity internally is easier than externally. Even with

127 all due diligence, a business partner can conduct unethical activities damaging company’s

128 integrity (Deloitte 2016). To protect their integrity, construction engineering companies

129 need to assess and mitigate the risks of their business partnerships.

\subsection{Business Partners in the Construction Industry}

131 Major construction and engineering companies often expand beyond national borders and 132 depend on third parties. In some cases, over $90 \%$ of the value of a contract is transferred to 133 these third parties (Watson and Serra 2016). Popular types of partnerships are Public134 Private Partnerships (PPPs), joint ventures and consortiums, and business developments, 135 each having their own advantages and disadvantages. 
136 The global financial crisis of 2007-2008 was the start of the boom in PPP projects (Osei-

137 Kyei and Chan 2015). Often presented as cheaper and involving lower risks, PPP often last

138 for generations (Bloomfield 2006). That said, PPP faces criticism because a complete and

139 true partnership is impossible if partners do not share the same objectives (profit, for

140 companies; social service, for governments). Furthermore, healthy competition in these

141 cases is impossible, because very few companies can afford to finance such projects

142 (Hodge and Greve 2017; Zhang 2005). Despite these disadvantages, PPP is valued by

143 governments because it makes major infrastructure projects possible.

144 The last decade has seen a jump in the popularity of joint ventures and consortiums. A joint

145 venture is an entity formed between parties to undertake economic activities, whereas a

146 consortium is an association between parties to achieve a common objective. These

147 partnerships are difficult because each party is acting both as an associate and as a 148 competitor at the same time (Ozorhon et al. 2008). This can lead to Conflicts of Interest 149 and collusion issues and must be managed properly.

150 Business development is crucial for construction and engineering companies (Smyth et al.

151 2016) whether prospecting new clients, working with sales agents, lobbyists, or marketing 152 (Conseil du trésor 2011). The organization is strongly impacted, should a business partner 153 act in a less-than-stellar fashion, since the partner is considered as a de facto representative 154 of both entities, and to be acting on behalf of this organization. These types of partnerships 155 are associated with a higher risk for companies. It is common to see compensation based 156 on sales or successful completion of tasks for these partnerships. This can easily tempt ill157 intentioned individuals to engage in Corruption \& Bribery (Teichmann 2018). 
158 Several other types of business partner relationships exist, including consulting services,

159 visa or customs services, local sponsors, and recruitment firms. Local sponsors are

160 common in many countries, particularly in the Middle East, for oil development projects

161 (El-Sabek and McCabe 2018).

162 2.3. Risk Management

163 Initially, experts did not include construction risks that are considered uninsurable, such as

164 morality, third party-related, etc. The latter are closely related to perception, which implies

165 that each person or company has a different way of viewing, understanding and interpreting

166 them (Coeckelbergh 2012). Emotions and perception are often overlooked in engineering

167 risk management (Richter and Paretti 2009). Also, the engineer training curriculum limits

168 the capacity to address issues from perspectives other than seeking technical solutions

169 (Guntzburger et al. 2018). Risk management professionals in construction engineering

170 must therefore include social sciences and perception to have an accurate representation of

171 the situation. To manage risks related to morality, companies draft codes of conduct and

172 ethics.

$173 \quad$ 2.4. Integrity-Related Risks

174 Following a review of four codes of ethics and business conduct from major players in the 175 construction and engineering industry, five integrity-related risks have been identified: 1) 176 risks associated to Human Rights, 2) Competition \& Antitrust, 3) Corruption \& Bribery, 177 4) Compliance with Regulations and 5) Conflict of Interest (CIMA+ 2018; SNC-Lavalin 178 2019; Stantec 2017; WSP 2018). 
179 Human rights and modern slavery constitute a major issue for companies' integrity. The 180 construction engineering industry requires a lot of materials and temporary migrant 181 workers for major projects (Anderson 2015; Millward 2017). Currently, more than 18240 million people are modern slaves (Anti-slavery international 2018). Modern slavery 183 generates illegal profits estimated at 150 billion USD annually (Institute of development 184 studies 2018). Working conditions are also part of this issue, considering the major impacts 185 on the reputation following a deadly incident.

186 Anti-collusion measures and antitrust laws are mandatory for a competitive market. In 187 construction and engineering, criminals use four techniques to create an apparently 188 competitive market (Conseil du trésor 2011). They consist of (1) the creation of fake bids 189 with abnormally high prices, (2) a long-term pattern of rotating winners, (3) contract 190 distribution to the same bidders, and (4) suppression of bids without notice or reason 191 (Locatelli et al. 2017).

192 Corruption is abused by an entity in a position of authority for personal gain, with bribery 193 being its most common form. The annual cost of corruption represents more than $5 \%$ of 194 global gross domestic product, standing at an estimated 3.5 trillion USD lost each year 195 (OECD 2014). Corruption increases inequality, especially in developing countries, while 196 reducing the overall efficiency of services and products.

197 Compliance with Regulations is expected to be more complicated and expensive with 198 increasing regulations. Money laundering and tax evasion affect taxpayers and 199 governments. Not reporting income from foreign sources and tax scheme promotion lead 200 to criminal prosecution (OECD 2012). Non-compliance with economic sanctions leads to 201 adverse consequences for companies. Since such sanctions are constantly evolving, they 
202 must keep abreast of current political events. Even where they are only apparent and well

203 managed, conflicts of interest often feature in adverse media coverage. Managing conflicts

204 of interest is necessary for objective decision-making, especially in public services (OECD 205 2003).

\subsubsection{Factors Influencing and Predicting Risk}

207 To ensure an efficient risk management process, companies assess risks according to 208 different factors. According to two third-party risk management references (Dow Jones 209 Risk \& Compliance 2018; NAVEX Gobal 2018), six main factors can predict and influence 210 integrity-related risks for business partners. The six main factors to be considered in 211 predicting integrity-related risks are: Type of Industry, Contract Complexity, Proximity to 212 Public Officials, Type of Third Party, Country, and Partner Profile.

213 A survey on bribe payers with more than 3000 business executives respondent revealed the 214 likelihood of bribes being paid by companies in 19 different industries (Transparency 215 International 2011). Public works contracts, construction, oil, gas and mining are the most 216 affected. An analysis of foreign bribery cases concluded between 1999 and 2014 identified 217 the industry of guilty companies (OECD 2014a). Extractives came first with 19\% of the 218 cases and construction followed with $15 \%$.

219 Type of Industry can also reveal potential Human Rights issues. Some industries prioritize 220 low wages with lower-skilled workers in abundant supply and seen as expendable (Blanton 221 and Blanton 2009). Self-regulation is directly related to CSR (Dashwood 2014). Therefore, 222 the level of self-regulation can predict a company's behaviour (Nysten-Haarala et al. 2015). 223 Oil, gas and mining industries are the least self-regulated and among the most 224 internationally active industries (Philp 2012). 
225 Contract Complexity is ambivalent in that some people consider it as a catalyst for risk and

226 others as a real factor; a catalyst because a multi-billion-dollar project can get more

227 exposure and media scrutiny if a company were to be found guilty (Chang et al. 2018).

228 Also, because the philosophy underlying integrity-related risk management is that even the

229 smallest act of corruption is punishable, and a project size must not affect how a company

230 deals with ethics and compliance (Scalza 2008). Notwithstanding this perspective, project

231 characteristics define corruption vulnerability (Locatelli et al. 2017; Nordin et al. 2013), as

232 shown in Table 1. Finally, accountability for each risk in a complex contract is challenging

233 for managers. Therefore, Contract Complexity is arguably a factor influencing integrity-

234 related risk evaluation.

235 Major projects often involve government and public officials. The main concern with this

236 factor is identifying if the relation involves a governmental agency or determine how much

237 ownership, control or influence is related to the government (Dow Jones Risk \&

238 Compliance 2018). This factor is directly related to Corruption \& Bribery risks (Ernst \&

239 Young 2013). Construction requires a lot of planning permission and licences, which can

240 lead to abuse (e.g., bribe to a public official for a faster work acceptance) to avoid cost or

241 time overruns. Also, projects in developing countries require many interactions with

242 government officials (directly related to the country's corruption perception index).

243 Finally, Proximity to Public Officials can also lead to Conflicts of Interests (OECD 2003a).

244 Some Types of Third Parties elevate the risk associated with Corruption \& Bribery. The

245 highest risk lies with third parties who are authorized to represent the company

246 (Transparency International UK 2016), such as a business development consultant,

247 commercial or sales agent, mandatory local partner, or lobbyist. The UK Bribery Act 
248 introduced a liability offense for companies who fail to prevent bribery (United Kingdom

249 2010). Therefore, evaluating risks associated with the Type of Third Party is mandatory to

250 protect the company's integrity.

251 Country is a non-negligible factor in evaluating risks. Indeed, organizations produce annual

252 data such as the corruption perception index (Global coalition against corruption 2018) to

253 that end. A Dow Jones survey revealed that more than $80 \%$ of companies risk rank the

254 countries of their third parties as part of their review process (Dow Jones Risk \&

255 Compliance 2018).

256 Country-based risks include the geopolitical situation, laws, regulations and sanctions. The

257 geopolitical situation and sanctions are closely related, with many developed countries

258 using sanctions as a foreign policy tool to signal the need for a change in behaviour or

259 policy of a specific country or region (Lektzian and Patterson 2015). Moreover, country-

260 based assessments can reveal risks in terms of tax havens, tax evasion and money

261 laundering with the financial secrecy index (Tax Justice Network 2018). Finally, the

262 Country can also be an indicator of the Human Rights situation, and many renowned

263 organizations, such as Human Rights Watch and the United Nations, address this issue

264 through annual country-based reports and rankings (Human Rights Watch 2018; United

265 Nations 2018).

266 Historical dealings with a particular third party must be reviewed and the occurrence of

267 unusual events analyzed (NAVEX Gobal 2018). Furthermore, the third party's risk

268 aversion and fit with the company must also be considered (Ozorhon et al. 2008). Adverse

269 media coverage of past misconduct influences the assessment and the level of due diligence

270 and scrutiny necessary for a third party. In some cases, this can in fact be an advantage 
271 because sanctions and prosecution often lead to redemption and very strong compliance

272 measures. Partner Profile also includes the type of compensation and payment terms

273 required by the third party. A great indicator of money laundering or tax evasion here could

274 be if the partner asks for a payment in an offshore institution, for example (Chong and

275 Lopez-De-Silanes 2015). Traditionally, blocking sanctions are applied to individuals and

276 entities, as well as to entities that are majority-owned by them. In this regard, the Office of

277 Foreign Assets Control (OFAC), for example, publishes the Specially Designated

278 Nationals and Blocked Persons List (SDN) (United States of America 2018). Furthermore,

279 considering the Partner Profile can reveal potential conflicts (OECD 2003a).

280 2.5. Performance Analysis

281 Performance analysis is used to gain strategic advantages. Adjustments and improvements

282 to business processes are necessary in a constantly evolving world (Cokins 2013). Ethical

283 leadership requires the capacity to assess a complex situation from the perspectives of

284 many (Lawton and Páez 2015). According to the concept of ethics of responsibility,

285 leadership is not generated by the self, but through engagement with others and a sense of

286 responsibility (Knights and O’Leary 2006). Therefore, an analytic tool for integrity

287 management must be interactive and not solely involve decision makers. Many

288 measurement and analysis methods exist for business management. The Political,

289 Economic, Socio-cultural, Technological, Legal and Environmental (PESTLE) analysis

290 and the Porter's five forces analysis investigate the external environment of an organization

291 (Cadle 2010). The Mission, Objectives, Strategy and Tactics (MOST) analysis and the

292 Boston Box investigate internal capabilities. Risk management depends on the external

293 environment to create the risks and the internal capabilities of the organization countering 
294 them. While being originally used as a strategic development tool, the SWOT analysis has

295 been adapted and used in many different contexts including construction engineering ones

296 (Rao et al. 2018; Zavadskas et al. 2011). The strength and weakness can investigate internal

297 capabilities while the threat and opportunity investigate the external environment. Also,

298 this method can be interactive by combining the answers of different parties. This analysis

299 specifies the target objectives, while identifying internal, external, positive, and negative

300 constraints. SWOT analysis is useful for strategic planning, especially if the analysis is

301 conducted with a specific objective, such as taking advantage of a new business

302 opportunity or implementing a new technology (Houben et al. 1999). Additionally, SWOT

303 analysis can be modified and adapted to specific situations other than general business

304 management (Kangas et al. 2017; Njoh 2017; Quezada et al. 2009). SWOT analysis is a

305 static strategy framework that needs to be used with a dynamic framework (Ghemawat

306 2016). Dynamic strategy frameworks come from creative thinking. Indeed, creativity

307 enables out of the box ideas that often withstand the test of time and a strong competitive

308 advantage. Some suggested sources for creativity (4 C's): contrast, combination,

309 constraints and context (Brandenburger 2017). The same author suggests using SWOT

310 analysis with one of the C's to challenge assumptions about company's characteristics and

311 what they mean for the organization (Brandenburger 2019a). By turning the tool upside

312 down (contrast method), it enables accounting for dynamic aspects such as the constant

313 changing business landscape (Brandenburger 2019b). Threat and weakness can be turned

314 into strength and opportunity. Indeed, the opposite is also true where an asset that helps the

315 company succeed becomes a liability and the likelihood of it happening increases over time 
316 when the context changes. As an example, having a big retail shop with on-site inventory

317 used to be successful, but is now a liability when competing with online giant retailers.

\subsection{Ethical Companies}

320 Often, the most ethical companies used to be the exact opposite. Strong penalties, financial 321 difficulties and other negative effects really act as an eye-opener. To survive, these 322 companies must have put in place strong compliance measures that led to redemption. As 323 an example, Fluor, a major construction engineering firm, is now on Ethisphere's most 324 ethical companies list despite past scandals related to fraud and others (Lu et al. 2016).

\section{Case Study Methodology}

\section{3.1. Presentation of the Company}

327 Following various corruption-related events in Qadhafi's Libya (Hachey 2012) and its 328 debarment from World Bank-financed projects for ten years (World Bank 2013), SNC329 Lavalin made drastic changes to its governance policies. With the creation of a department 330 dedicated solely to protecting the company's integrity and preventing such events from 331 happening again, SNC-Lavalin is now a leader in ethical and compliance management and 332 earned the prestigious Compliance Leader Verification from the Ethisphere Institute in 333 2019. After creating policies to manage integrity and conducting their first integrity-related 334 risk assessment in 2014, the company never stopped improving their program and their 335 CEO earned a chair at world economic forum global anticorruption initiative.

336 Third-party risk management is mandatory in the company, and thousands of potential 337 business partners are checked annually. The database contains around two thousand active 
338 business partners, which is a small number compared to the hundreds of thousands of

339 business partners of financial institutions but is still a challenging amount to monitor due

340 to the variety of activities and relationship to the engineering company. The goal is to

341 propose a methodology for construction engineering companies to evaluate which

342 indicators can reveal integrity-related risks and to include experts' opinions by interviews

343 based on the strength, weakness, opportunity and threat analysis. From the contrast method,

344 the weakness and treat are transformed into competitive advantage of the company.

\subsection{Current Practices in Business Partner Risk Ranking}

347 At SNC-Lavalin, business partners are risk-ranked based on a series of questions and an 348 integrity check. Points are assigned to each question and the sum of the assessment 349 distinguish low, medium and high-risk partners. Questions for the business partner 350 evaluation cover specific risk factors, as shown in Table 2. Contract Complexity and Type 351 of Industry were not yet covered by the questions. Also, some risk factors were covered in 352 greater detail than others; an example is the third-party type as compared to the country 353 risk. Finally, the integrity check covered three Dow Jones lists (Dow Jones 2016): Watch 354 lists (Public Services and Procurement Canada, World Bank and other development banks 355 lists of ineligible entities and economic sanctions imposed by various governments), 356 Politically Exposed Person/State Owned Company and Adverse media coverage, and one 357 list from SNC-Lavalin's references.

\subsection{Case Participants/Experts}

359 The interviews were conducted among 14 SNC-Lavalin's employees, including the 6 360 sector officers, 7 regional officers and the corporate officer (Figure 1). Experience and 
361 knowledge of the experts were the two main characteristics for the selection. The

362 participants needed to have a comprehensive view of the risk management situation in the

363 company and to have enough expertise on integrity, ethics and compliance. The officers

364 have different backgrounds and come from different countries and industries. This

365 heterogeneous population is composed of lawyers, engineers, business administrators and

366 human resources specialists from the United States, United Arab Emirates, India, and more.

367 At company scale, this population is representative and covers most business units of the 368 company.

\subsection{SWOT and Interviews Analysis Processes}

370 A qualitative approach was used in conducting a SWOT analysis of the business partners'

371 tool. The first step of the process involved interviews with the 14 experts at SNC-Lavalin.

372 Interview results gave fragmented agreement for each SWOT category. Also, it gave the

373 perception of the experts regarding the different risk factors and their influence on specific

374 risks. For this research, a modified version of the SWOT analysis was used. Since the

375 analysis pertains to a management tool rather than general economic/business

376 performance, the main objective was not necessarily related to profit and economic gains.

377 Opportunities were replaced by positive developments because they are associated with a

378 better understanding of the risk factors, new data or tool, laws and others in integrity

379 related-risk management. The strengths and weaknesses are related to the current tool, and

380 the threats to forthcoming risks in the engineering and construction industry. Interviews

381 were divided into five sections, each one addressing a risk determined through the literature

382 review: Antitrust \& Competition, Conflict of Interest, Compliance with Regulations (trade,

383 money laundering, and tax), Human Rights, and Corruption \& Bribery. The six risk factors 
384 stated in the literature review were used, and respondents needed to rank them. A ranking 385 of 1 for Country regarding Corruption \& Bribery means that Country is the best indicator 386 allowing the detection of corruption and that would give Country 6 points for this risk in 387 the interviews (Table 3 ). Non-applicable gives 0 points. The research and analytic process 388 used is shown in Figure 2. The scores for the risk indicators were gathered in a single table 389 where an average was made. The answers to the SWOT categories were analyzed to find 390 recurring answers and include them to the final SWOT themes. Finally, based on the 391 contrast method, the tool is turned upside down in the discussion section to see how 392 weakness and threat can be turned in strength and positive development and vice versa.

395 Consolidated results of the risk factors consisted of an average of fourteen different 396 respondents (Table 4). Table 4 presents the capacity of each risk factors to detect each 397 integrity-related risk according to the participant's interviews. A score of 0 means that the 398 factor was useless at detecting the risk, and the closer it got to 6 , the better it is at detecting 399 the risk. The boxes with an asterisk in Table 4 represent the best risk factor for each 400 integrity-related risk. The standard deviations of the respondents' answers for each of the 401 risk factors are then presented (Table 5). The boxes with an asterisk in Table 5 represents 402 low standard deviations, while the ones with a cross show high standard deviations. A high 403 deviation is related to a divergence in opinions between the respondents.

404 By analyzing the interviews' answers, it was determined that the Type of Third Party is 405 crucial for both Antitrust \& Competition and Conflict of Interest. The highest risk lies with 
partners who are authorized to represent the company. Country is a main indicator for three

407 of the five major risks at SNC-Lavalin and it is an important indicator of corruption

408 perception, human rights status and financial secrecy. Partner Profile was consistently

409 grade ranked for the five risks (more consistent than the first and second indicators).

410 Indeed, Partner Profile provides data for each risk (past behaviour for Corruption \&

411 Bribery, Antitrust \& Competition and Human Rights, relation for Conflict of Interest and

412 payment/financial information for Compliance with Regulations). Proximity to Public

413 Officials did not score highly for most risks, this indicator is critical for Corruption \&

414 Bribery and Conflict of Interest, especially in riskier countries highlighted by Transparency

415 International. The combination of this risk factor with Country or Type of Third Party can

416 reveal a strong risk of Corruption \& Bribery or Conflict of Interest. Type of Industry acts

417 as a significant indicator for Antitrust \& Competition and Human Rights. As mentioned,

418 industry self-regulation is a great indicator for the different risks. Finally, Contract

419 Complexity has a significant impact on Antitrust \& Competition, and Compliance with

420 Regulations.

421 The standard deviations show mixed perceptions for the Type of Industry. Indeed, the two

422 greater deviations are for this factor, meaning that some respondents consider it

423 meaningful, while others less. This can be explained by the nature of the respondents. A

424 sector integrity officer has a narrower overall view of the other sectors, which leads to a

425 biased judgment of his own sector. This trend also appears, but less drastically, for the

426 Country. The main factor affecting the standard deviations is the regional and sector

427 integrity officer's biases. Also, the standard deviations show that the results for Human

428 Rights and Conflict of Interest are very stable as compared to the other risks. As discussed, 
429 it is necessary to include perception in risk management, especially for integrity-related

430 risks. More than half of the factors have a relatively high standard deviation, and this must

431 be reflected in the business partner compliance process. However, for a major company

432 like SNC-Lavalin, it is crucial to adhere to a single prescriptive business partner

433 compliance process. The integrity department receives cases from different business units, 434 and consistency allows officers to avoid mistakes.

\section{4.2. SWOT Analysis}

436 The results for the SWOT analysis were gathered for the five risks (Figure 3). Results for 437 Antitrust \& Competition confirm the importance of the indicator Type of Third Party. As 438 mentioned in the literature, some relationships elevate the risks and, in this case, a joint 439 venture or a consortium can reduce the number of bidders and affect healthy competition. 440 Also, Proximity with Public Officials can reveal potential collusion particularly if the 441 partner is working in business development. The results also confirm the necessity to 442 include the Type of Industry and Contract Complexity indicators in a future tool because, 443 as mentioned, they can reveal risks associated to a cartel in the construction engineering 444 industry. The SWOT results concord with the score per risk (Table 4).

445 The results for Conflict of Interest confirm the importance of the indicators Proximity with 446 Public Officials and Type of Third Party, particularly if the partner is working in business 447 development for a public project. The results also highlight the importance of going deeper 448 into the Partner Profile since it can reveal internal Conflict of Interest between the partner 449 and the originator. The SWOT results concord with the score per risk (Table 4). 
450 The results for Compliance with Regulations confirm the importance to include the 451 Country indicator because, sanctions are often on a country and there is a lot of data 452 produced about financial secrecy and tax havens. The results also highlight the importance 453 to adjust the risk level according to the Country indicator since it is considered the most 454 important for that risk (Table 4). Finally, including Contract Complexity and going deeper 455 into the Partner Profile can uncover beneficial owners whom could be sanctioned. The 456 SWOT results agree with the score per risk (Table 4).

457 The results for Human Rights confirm the importance of the Country indicator to detect 458 risks related to Human Rights. Indeed, many organizations produce country reports and 459 rankings. It also highlights the importance of the Partner Profile indicator because adverse 460 media coverage can reveal breaches in Human Rights. The results do not include the Type 461 of Industry indicator even if it was ranked as an important one in the score per risk (Table 462 4). As mentioned, lower-skilled workers' industries tend to see Human Rights as less 463 important (Blanton and Blanton 2009).

464 The results for Corruption \& Bribery confirm the importance to include the Country, 465 Proximity with Public Officials and Type of Third-Party indicators. Many organizations 466 produce annual rankings on corruption per country and a third party who is authorized to 467 represent the company with ties to public officials can reveal important risks of Corruption 468 \& Bribery. The results also highlight the importance to cover the Partner Profile deeper 469 since it can reveal potential beneficial owners. The respondents did not include Contract 470 Complexity even if the literature demonstrates that it can be an important indicator. The 471 results agree with the score per risk (Table 4). 
473 Integrity and ethics management are constantly evolving. Associated data, population

474 perception, technologies and legislation are changing, and the tool of the trade needs to 475 reflect that (Slagmulder and Devoldere 2018). A comprehensive view of the whole process 476 is necessary for a complete improvement. A good assessment is useless if it cannot be 477 adjusted over time with the help of ongoing monitoring and tracking of the business 478 partner. Furthermore, regulatory, data and technological monitoring are necessary to keep 479 the whole process up to date. A process that does not include the latest laws or data becomes 480 irrelevant very quickly.

481 A qualitative approach such as SWOT is suited for this research. Indeed, given the very 482 limited number of experts on this subject within such a big company, SWOT allows 483 researchers to adapt the method in an interactive process and collect opinion easily about 484 internal and external context. As a first step to better circumscribe the integrity-related tool, 485 SWOT enabled a broader perspective by letting experts answer openly. In other situations, 486 with a much higher number of participants, this approach is not applicable. The core idea 487 of SWOT can still be used but with close answers (e.g. multiple choices, one-word answer, 488 etc.). Regarding research questions, answers from interviewees revealed that a generic tool 489 covering only corruption does not protect a construction and engineering company's 490 integrity. Furthermore, answers also revealed potential solutions to investigate and assess 491 thoroughly business partners in this sector. Finally, SWOT enables researchers to go 492 beyond these results by turning the tool upside down with the contrast method. This allows 493 long-term analysis and offers new possibilities to turn negative aspects into positive ones 494 as shown in the next discussion subsections. 
497 The weighting of the new scoring system must draw from the interview's ranking of the 498 risk factors. However, only taking these into account would not be reliable. Indeed, some 499 indicators are very critical in specific projects or situation. For example, Proximity to 500 Public Officials in a Country with a high perceived level of corruption is a very critical 501 indicator (PACI 2013). The reviewed indicators often interact and must not be assessed 502 separately only. Therefore, findings suggest that a good tool must include a scoring system 503 based on the interviews, with exceptions based on past events or expert opinion. Although 504 fourteen participants are a small number to conduct a study and rank risks, including input 505 from additional company employees would not improve the assessment due to their 506 unfamiliarity with integrity management concepts. Despite being a leader in this domain, 507 few of SNC-Lavalin's experts can answer integrity-related questions with a broader 508 perspective. Having more experts would mean more solid results. Since answers were 509 highly related to company's internal activities, having experts from other firms was not 510 considered pertinent, but could be if the goal was to identify threats and positive 511 developments only (external context).

\section{$512 \quad$ 5.2. SWOT}

514 According to the findings, the main strength for all the risks is undoubtedly the Integrity 515 Check. Questions about partner's experience, audited financial reports and suppliers' code 516 of conduct can also respectively reveal partner's maturity, financial irregularities and 517 Human Rights risks. Corruption \& Bribery are also greatly covered by the tool since it was 518 designed for this specific risk. Using the contrast method, it is possible to evaluate how the 
519 main strength (integrity check) can turn into a weakness. Indeed, these checks have

520 technological flaws. The first one is the numerous results generated by these checks. Too

521 much information can lead to analyst overlooking important aspects and data availability

522 is expected to rise significantly (Deloitte 2018). The second one is the beneficial ownership

523 schemes getting more complex (Jong et al. 2017). Only relying on the check can allow

524 fraudulent owners to slip below the radar. To mitigate those flaws, integrity departments

525 must focus on reducing false positives in the integrity check and advocate for more

526 transparent ownership in problematic countries.

527 Ongoing monitoring was one of the main weakness of the integrity tool. It is already 528 automated in the current tool and generates many notifications. Also, money laundering, 529 tax evasion and sanctions are treated separately but the tool must reveal possible breaches 530 of Compliance with Regulations and notify those concerned. By turning the main weakness 531 upside down with the contrast method (Brandenburger 2019), it is noted that a more precise 532 ongoing monitoring become a strength. Improving ongoing monitoring would also benefit 533 the integrity check. As mentioned, reducing false positives could mitigate the risks of 534 integrity check turning into a weakness. Therefore, reducing false positives and narrowing 535 researches while monitoring partners can easily be adapted to maintain the strength of the 536 integrity check. Analysts could spend less time eliminating irrelevant information, thus 537 having more time to assess partners consistently.

538 The positive developments were all related to more laws and regulations and access to 539 information. Governments are enforcing laws and penalties. From a contrast (upside down) 540 perspective, despite being good news for the public, these laws can become a threat to 541 companies. Indeed, following their evolution is a complex task when the company has 
542 business in dozens of countries each having their own laws. To mitigate this positive

543 development turning into a threat, SNC-Lavalin must allow more resources on this aspect

544 and integrate them in the integrity department.

545 Without applying the contrast strategy, participants also identified more laws and 546 regulations as a threat. Also, globalization has led to complex supply chains. Keeping track

547 of all the activities is challenging (CIOB 2016). Improving and forcing supplier 548 transparency can turn the threat into a positive development for the company. Indeed, it 549 can increase business opportunities for projects requiring social or environmental 550 certification. Developing such an expertise can enable SNC-Lavalin to strengthen its 551 leadership role within the construction engineering sector. More and more procurement 552 schemes require certification, and these are expected to grow with the increased awareness 553 about social and environmental issues.

\section{Conclusion}

555 By reviewing the literature and analyzing the data from the interviews, gaps in the current 556 risk assessment tool were identified, and suggestions for the future business partner 557 compliance tool were made regarding the integration of other risk indicators, the strategic 558 use of data and the interactive process in integrity management for SNC-Lavalin. A case 559 study interview was created to investigate the perception of experts using the current tool 560 on an almost daily basis and validate how construction engineering companies can assess 561 their tool for complete integrity protection. There was very high interest among participants 562 for improving the current tool. Regarding the research questions, it was determined that the 563 ready-made tool did not protect the company's integrity and that companies must involve 
564 their experts in order to create a tool with more risks included to assess their business

565 partners and protect their integrity. Findings show the importance of having an interactive

566 process and combining different performance analysis to assure integrity management.

567 Indeed, answers were quite different depending on the participants because of their

568 geographic or sectorial context. Also, with integrity being a relatively new concept,

569 awareness needs to be done among employees and other companies. The scientific value

570 of this article is a reflection on how construction engineering companies can assess, and

571 enhance eventually, their third-party management to protect their integrity. Very few

572 scientific papers have studied this aspect and were mostly limited to the financial sector.

573 With construction engineering companies having less business partners than financial ones,

574 recommended resources and strategy were not adapted to their needs.

575 The study was conducted at SNC-Lavalin and the views presented by the experts reflect

576 some of the integrity management team's perspective. Further research should focus on

577 different types of companies, such as general contractors or engineering consultants. Also,

578 the company's past influences its current behaviour and its risk aversion. A company

579 involved only in the local market would not have the same risks and indicators in

580 comparison to a multinational company. Limitations are mostly related to the internal

581 context aspects of the tool and the precise results themselves. Namely, the importance of

582 each risk and indicators and the strengths and weaknesses results. The proposed

583 methodology to assess integrity tools is applicable to other construction engineering

584 companies. Interviews, SWOT and contrast analysis proved to be an efficient way to assess

585 and improve the company's integrity tool for third parties. More studies like this one can

586 help standardize integrity management and organizations with fewer financial resources 
587 can benefit from this by implementing integrity tool and processes at a low cost (the same 588 organization who sometimes act as a third party for multinationals) resulting in a more 589 transparent, honest and fair industry.

590 Data Availability

591 Some or all data, models, or code generated or used during the study are available from the 592 corresponding author by request (SWOT results for each respondent and score per risk 593 results for each respondent).

\section{Acknowledgements}

595 This research was fully supported by SNC-Lavalin and Mitacs Acceleration program. We 596 thank our dear colleagues from the Integrity department who provided great expertise to 597 assist in the research. The author would also like to thank Professor Marc Tassé, member 598 of the Canadian Centre of Excellence for Anti-Corruption and Ottawa University, for his 599 insights and precious support throughout this research.

600

601 
Ameyaw, E. E., Pärn, E., Chan, A. P. C., Owusu-Manu, D.-G., Edwards, D. J., and Darko, A. (2017). "Corrupt Practices in the Construction Industry: Survey of Ghanaian Experience." Journal of Management in Engineering, 33(6), 05017006.

Anderson, B. (2015). "Migrant Domestic Workers: Good Workers, Poor Slaves, New Connections." Social Politics: International Studies in Gender, State \& Society, 22(4), 636652.

Anti-slavery international (2018). "Slavery today." < https://www.antislavery.org/slaverytoday/modern-slavery>. (25 octobre 2018).

Badaracco, J. L., and Ellsworth, R. R. (1991). "Leadership, Integrity and Conflict." Journal of Organizational Change Management, 4(4), 46-55.

Blanton, S. L., and Blanton, R. G. (2009). "A Sectoral Analysis of Human Rights and FDI: Does Industry Type Matter?*." International Studies Quarterly, 53(2), 469-493.

Bloomfield, P. (2006). "The Challenging Business of Long-Term Public-Private Partnerships: Reflections on Local Experience." Public Administration Review, 66(3), 400-411.

Bonn, I., and Fisher, J. (2005). "Corporate Governance and Business Ethics: insights from the strategic planning experience*." Corporate Governance: An International Review, 13(6), 730-738.

Brandenburger, A. (2017). "Where Do Great Strategies Really Come From?" Strategy Science, 2(4), 220-225.

Brandenburger, A. (2019). "Strategy needs creativity: an analytic framework alone won't reinvent your business." Harvard Business Review March/April, 3-9.

Brandenburger, A. (2019a). "Are your company's strengths really weaknesses?" Harvard business review.

Brandenburger, A. (2019b). "Strategy needs creativity." Harvard business review.

Brenkert, G. G. (2004). Corporate integrity \& accountability, Thousand oaks.

Bull, J. W., Jobstvogt, N., Böhnke-Henrichs, A., Mascarenhas, A., Sitas, N., Baulcomb, C., Lambini, C. K., Rawlins, M., Baral, H., Zähringer, J., Carter-Silk, E., Balzan, M. V., Kenter, J. O., Häyhä, T., Petz, K., and Koss, R. (2016). "Strengths, Weaknesses, Opportunities and Threats: A SWOT analysis of the ecosystem services framework." Ecosystem Services, 17, 99-111.

Cadle, J. (2010). Business analysis techniques - 72 essential tools for success, BCS.

Chang, T., Deng, X., Hwang, B.-G., and Zhao, X. (2018). "Political risk paths in international construction projects: Case study from chinese construction enterprises." Advances in Civil Engineering, 11.

Chong, A., and Lopez-De-Silanes, F. (2015). "Money Laundering and Its Regulation." Economics \& Politics, 27(1), 78-123.

CIMA+ (2018). "Our code of ethics and conduct." 32.

CIOB (2016). "Tackling modern slavery in construction supply chains." $\mathrm{CIOB}$, ed.

Coeckelbergh, M. (2012). "Moral Responsibility, Technology, and Experiences of the Tragic: From Kierkegaard to Offshore Engineering." Science and Engineering Ethics, 18(1), 3548.

Cokins, G. (2013). Strategic Business Management: From Planning to Performance.

Conseil du trésor (2011). "Coffre à outils pour préserver l'intégrité des contrats publics." C. d. trésor, ed., Gouvernement du Québec, Québec, 128.

Dainty, M. M. A. (2009). Corporate Social Responsibility in the Construction Industry, Taylor \& Francis, United Kingdom. 
Dashwood, H. S. (2014). "Sustainable Development and Industry Self-Regulation:Developments in the Global Mining Sector." Business \& Society, 53(4), 551-582.

Deloitte (2016). "Third party governance and risk management: The threats are real." Global survey, D. UK, ed., 38.

Deloitte (2018). "Al and Risk Management: Innovating with confidence." C. f. r. strategy, ed., 29.

Deng, X., Low, S. P., Li, Q., and Zhao, X. (2014). "Developing Competitive Advantages in Political Risk Management for International Construction Enterprises." Journal of Construction Engineering and Management, 140(9), 04014040.

Dow Jones (2016). "Content definition guide." R. a. Compliance, ed., 45.

Dow Jones (2018). "Third party risk management - uncover emerging trends." D. J. R. Compliance, ed., 7.

Dow Jones Risk \& Compliance (2018). "Third Party Risk Management - Uncover emerging trends." 7.

El-Sabek, L. M., and McCabe, B. Y. (2018). "Coordination Challenges of Production Planning in the Construction of International Mega-Projects in The Middle East." International Journal of Construction Education and Research, 14(2), 118-140.

Ernst \& Young (2013). "Managing bribery and corruption risks in the construction and infrastructure industry." E. management, ed., 24.

Gallas, D. (2019). "Brazil's Odebrecht corruption scandal explained." BBC South America, BBC. Ghemawat, P. (2016). "Evolving ideas about business strategy." Cambridge university press, 09. Global coalition against corruption (2018). "Transparency International Corruption Perception Index."

Guntzburger, Y., Pauchant, T. C., and Tanguy, P. A. (2018). "Empowering Engineering Students in Ethical Risk Management: An Experimental Study." Science and Engineering Ethics.

Hachey, I. (2012). "Prison de Gharyan, projet controversé de SNC-Lavalin." La PresseMontréal.

Ho, C. M. F. (2011). "Ethics management for the construction industry: A review of ethical decision-making literature." Engineering, Construction and Architectural Management, 18(5), 516-537.

Hodge, G. A., and Greve, C. (2017). "On Public-Private Partnership Performance:A Contemporary Review." Public Works Management \& Policy, 22(1), 55-78.

Houben, G., Lenie, K., and Vanhoof, K. (1999). "A knowledge-based SWOT-analysis system as an instrument for strategic planning in small and medium sized enterprises." Decision Support Systems, 26(2), 125-135.

Human Rights Watch (2018). "World Report." HRW, ed., 600.

Institute of development studies (2018). "Modern slavery briefing." I. f. d. studies, ed.

Jaber, J. O., Elkarmi, F., Alasis, E., and Kostas, A. (2015). "Employment of renewable energy in Jordan: Current status, SWOT and problem analysis." Renewable and Sustainable Energy Reviews, 49, 490-499.

Jong, J. d., Meyer, A., and Owens, J. (2017). "Using blockchain for transparent beneficial ownership registers." W. University, ed.International Tax Review, 4.

Kangas, J., Tikkanen, J., Leskinen, P., Kurttila, M., and Kajanus, M. (2017). "Developing hybrid SWOT methodologies for choosing joint bioeconomy co-operation priorities by three Finnish universities." Biofuels, 8(4), 459-471.

Knights, D., and O'Leary, M. (2006). "Leadership, Ethics and Responsibility to the Other." Journal of Business Ethics, 67(2), 125-137.

Lawton, A., and Páez, I. (2015). "Developing a Framework for Ethical Leadership." Journal of Business Ethics, 130(3), 639-649. 
Lektzian, D., and Patterson, D. (2015). "Political Cleavages and Economic Sanctions: The Economic and Political Winners and Losers of Sanctions." International Studies Quarterly, 59(1), 46-58.

Locatelli, G., Mariani, G., Sainati, T., and Greco, M. (2017). "Corruption in public projects and megaprojects: There is an elephant in the room!" International Journal of Project Management, 35(3), 252-268.

Lu, W., Ye, M., Flanagan, R., and Ye, K. (2016). "Corporate Social Responsibility Disclosures in International Construction Business: Trends and Prospects." Journal of Construction Engineering and Management, 142(1), 04015053.

Matthews, P. (2016). "This is why construction is so corrupt." $<$ https://www.weforum.org/agenda/2016/02/why-is-the-construction-industry-socorrupt-and-what-can-we-do-about-it/>. (2019).

Mhetre, K. (2016). "Risk management in construction industry." International Journal of Engineering Research, 5(1), 153-155.

Millward, P. (2017). "World Cup 2022 and Qatar's construction projects: Relational power in networks and relational responsibilities to migrant workers." Current Sociology, 65(5), 756-776.

NAVEX Gobal (2018). "Ethics \& Compliance Third-Party Risk Management Benchmark Report." 56.

Njoh, A. J. (2017). "The SWOT model's utility in evaluating energy technology: Illustrative application of a modified version to assess the sawdust cookstove's sustainability in SubSaharan Africa." Renewable and Sustainable Energy Reviews, 69, 313-323.

Nordin, R. M., Takim, R., and Nawawi, A. H. (2013). "Behavioural Factors of Corruption in the Construction Industry." Procedia - Social and Behavioral Sciences, 105, 64-74.

Nysten-Haarala, S., Klyuchnikova, E., and Helenius, H. (2015). "Law and self-regulation Substitutes or complements in gaining social acceptance?" Resources Policy, 45, 52-64.

OECD (2003). "Managing conflict of interest in the public service."

OECD (2003a). "Recommendation of the council on guidelines for managing conflict of interest in the public service." OECD, ed., OECD, 14.

OECD (2012). "Forum on tax administration: reducing opportunities for tax non-compliance in the underground economy." 72.

OECD (2014). "The rationale for fighting corruption." 4.

OECD (2014a). "Foreign bribery report: An analysis of the crime of bribery of foreign public officials." 51.

Oladinrin, O. T., and Ho, C. M.-F. (2016). "Enabling Ethical Code Embeddedness in Construction Organizations: A Review of Process Assessment Approach." Science and Engineering Ethics, 22(4), 1193-1215.

Osei-Kyei, R., and Chan, A. P. C. (2015). "Review of studies on the Critical Success Factors for Public-Private Partnership (PPP) projects from 1990 to 2013." International Journal of Project Management, 33(6), 1335-1346.

Ozorhon, B., Arditi, D., Dikmen, I., and Birgonul, M. T. (2008). "Effect of Partner Fit in International Construction Joint Ventures." Journal of Management in Engineering, 24(1), 12-20.

PACI (2013). "Good Practice Guidelines on Conducting Third-Party Due Diligence." World economic forum, 48.

Philp, R. B. (2012). Environmental issues for twenty-first century and their impact on human health. 
Quezada, L. E., Cordova, F. M., Palominos, P., Godoy, K., and Ross, J. (2009). "Method for identifying strategic objectives in strategy maps." International Journal of Production Economics, 122(1), 492-500.

Rao, M., Chhabria, R., Gunasekaran, A., and Mandal, P. (2018). "Improving competitiveness through performance evaluation using the APC model: A case in micro-irrigation." International Journal of Production Economics, 195, 1-11.

Richter, D. M., and Paretti, M. C. (2009). "Identifying barriers to and outcomes of interdisciplinarity in the engineering classroom." European Journal of Engineering Education, 34(1), 29-45.

Sadgrove, K. (2015). The complete guide to business risk management, Routledge.

Scalza, A. A. "Ethics in the Construction Industry: Teaching students ethics in this 21st century global market." Proc., Mid-Atlantic conference of the American Society for Engineering Education, 10.

Shen, W., Li, G., Lin, C.-L., and Liang, H. "Foundation of a Framework to Support Compliance Checking in Construction Industry." Springer International Publishing, 111-122.

Slagmulder, R., and Devoldere, B. (2018). "Transforming under deep uncertainty: A strategic perspective on risk management." Business Horizons, 61(5), 733-743.

Smyth, H., Fellows, R., Liu, A., and Tijhuis, W. (2016). "Editorial for the Special Issue on Business Development and Marketing in Construction." Construction Management and Economics, 34(4-5), 205-217.

SNC-Lavalin (2019). "Code of ethics and business conduct."

Stantec (2017). "Sustainability report." 78.

Stevens, B. (2008). "Corporate Ethical Codes: Effective Instruments For Influencing Behavior." Journal of Business Ethics, 78(4), 601-609.

Tang, W., Qiang, M., Duffield, C. F., Young, D. M., and Lu, Y. (2007). "Risk Management in the Chinese Construction Industry." Journal of Construction Engineering and Management, 133(12), 944-956.

Tax Justice Network (2018). "Financial Secrecy Index." <https://www.financialsecrecyindex.com/introduction/fsi-2018-results >. (2018-12-13, 2018).

Teichmann, F. M. J. (2018). "Anti-bribery compliance incentives." Journal of Financial Crime, 25(4), 1105-1110.

Transparency International (2011). "Bribe payers index." 32.

Transparency International UK (2016). "Managing third party risk: only as strong as your weakest link." T. International, ed., 64.

United Kingdom (2010). "UK Bribery Act."

United Nations (2018). "Human Development Indices and Indicators." U. N. D. Program, ed., 123.

United States of America (2018). "Specially Designated Nationals and Blocked Persons list (SDN)." < https://www.treasury.gov/resource-center/sanctions/SDNlist/pages/default.aspx>. (2018-11-29, 2018).

United States Sentencing Commission (2018). "Guidelines Manual." U. s. s. commission, ed., 608.

Watson, S., and Serra, J. (2016). "Managing and creating value from third-party risk." Renewable Energy Focus, 17(3), 99-101.

World Bank (2013). "World Bank Debars SNC-Lavalin Inc. and its Affiliates for 10 years." <http://www.worldbank.org/en/news/press-release/2013/04/17/world-bank-debarssnc-lavalin-inc-and-its-affiliates-for-ten-years>. (2018). 
791 WSP (2018). "Code of conduct." 28.

792 Zavadskas, E. K., Turskis, Z., and Tamosaitiene, J. (2011). "Selection of construction enterprises 793 management strategy based on the SWOT and multi-criteria analysis." Archives of Civil 794 and Mechanical Engineering, 11(4), 1063-1082.

795 Zhang, X. (2005). "Criteria for selecting the private-sector partner in public-private 796 partnerships." Journal of Construction Engineering and Management, 131(6), 631-644.

797

798 
Table 1. Project characteristics and corruption vulnerability adapted from (Locatelli et al. 2017)

\begin{tabular}{ll}
\hline Characteristic & Description \\
\hline Size & Easier to hide bribes and inflated claims in large projects \\
Uniqueness & Budget costs difficult to compare and therefore it is easier to inflate \\
Number of contractual links & $\begin{array}{l}\text { Each link provides an opportunity for someone to pay a bribe } \\
\text { Project complexity }\end{array}$ \\
& $\begin{array}{l}\text { Very complex projects create mismanagement or poor design, which can } \\
\text { hide bribes or inflate claims }\end{array}$
\end{tabular}

801

802 Table 2. Risks covered by SNC-Lavalin's business partner compliance tool

\begin{tabular}{|c|c|}
\hline Questions & Risk factors \\
\hline $\begin{array}{l}\text { Will the Business Partner conduct business development } \\
\text { for SNC-Lavalin? }\end{array}$ & Type of Third Party \\
\hline $\begin{array}{l}\text { Will the business partner be directly or indirectly } \\
\text { interacting with government officials? }\end{array}$ & $\begin{array}{l}\text { Type of Third Party and Proximity to } \\
\text { Public Officials }\end{array}$ \\
\hline $\begin{array}{l}\text { Has the business partner been recommended by } \\
\text { government officials? }\end{array}$ & Proximity to Public Officials \\
\hline What is the purpose of the engagement? & Type of Third Party \\
\hline $\begin{array}{l}\text { All countries where the business partner is expected to } \\
\text { perform his mandate with or on behalf of SNC-Lavalin } \\
\text { must be selected. Also add the home base country of the } \\
\text { business partner. }\end{array}$ & Country \\
\hline $\begin{array}{l}\text { How is the business partner compensated by SNC- } \\
\text { Lavalin (payment or other benefit)? }\end{array}$ & Partner Profile, Type of Third Party \\
\hline $\begin{array}{l}\text { Has the business partner requested any unusual payment } \\
\text { terms or rates? }\end{array}$ & Partner Profile \\
\hline Check against the Integrity Database. & Partner Profile \\
\hline
\end{tabular}
803

804 Table 3. Points allowed for the score per risk according to the rank

\begin{tabular}{|l|c|c|c|c|c|c|}
\hline Rank & 1 & 2 & 3 & 4 & 5 & 805 \\
\hline Points allowed & 6 & 5 & 4 & 3 & 2 & 1 \\
\hline
\end{tabular}


Table 4. Risk indicators importance regarding each risk

\begin{tabular}{|l|c|c|c|c|c|}
\hline \multirow{2}{*}{ Risk indicators } & \multicolumn{5}{|c|}{ Average score per risk } \\
\cline { 2 - 6 } & $\begin{array}{c}\text { Antitrust \& } \\
\text { Competition }\end{array}$ & $\begin{array}{c}\text { Corruption } \\
\text { \& Bribery }\end{array}$ & $\begin{array}{c}\text { Human } \\
\text { Rights }\end{array}$ & $\begin{array}{c}\text { Conflict of } \\
\text { Interest }\end{array}$ & $\begin{array}{c}\text { Compliance } \\
\text { with Regulations }\end{array}$ \\
\hline $\begin{array}{l}\text { Proximity to Public } \\
\text { Officials }\end{array}$ & 2.4 & $4.9 *$ & 1.1 & 4.6 & 3.0 \\
\hline Country & 2.6 & 4.7 & $4.9 *$ & 2.1 & $4.7 *$ \\
\hline Partner Profile & 3.3 & 3.1 & 3.9 & 3.4 & 2.9 \\
\hline Type of Third Party & $5.0 *$ & 3.7 & 3.1 & $5.7 *$ & 3.7 \\
\hline Type of Industry & 3.7 & 2.1 & 3.9 & 2.0 & 3.1 \\
\hline Contract Complexity & 3.6 & 2.4 & 1.9 & 2.7 & 3.4 \\
\hline
\end{tabular}

812 Table 5. Standard deviation for each score of the Table 4

\begin{tabular}{|l|c|c|c|c|c|}
\hline \multirow{2}{*}{ Risk indicators } & \multicolumn{5}{|c|}{ Standard deviation } \\
\cline { 2 - 6 } & $\begin{array}{c}\text { Antitrust \& } \\
\text { Competition }\end{array}$ & $\begin{array}{c}\text { Corruption } \\
\text { \& Bribery }\end{array}$ & $\begin{array}{c}\text { Human } \\
\text { Rights }\end{array}$ & $\begin{array}{c}\text { Conflict of } \\
\text { Interest }\end{array}$ & $\begin{array}{c}\text { Compliance } \\
\text { with Regulations }\end{array}$ \\
\hline $\begin{array}{l}\text { Proximity to Public } \\
\text { Officials }\end{array}$ & 1.99 & 1.46 & $0.82 *$ & $0.98 *$ & 1.63 \\
\hline Country & 1.9 & 1.11 & $0.82 *$ & 1.87 & 1.89 \\
\hline Partner Profile & 1.25 & 1.95 & $0.55 *$ & 1.27 & 1.97 \\
\hline Type of Third Party & $0.82 *$ & 1.11 & 1.3 & $0.49 *$ & $0.76 *$ \\
\hline Type of Industry & $2.56+$ & 1.46 & 1.68 & $0.82 *$ & $2.19+$ \\
\hline Contract Complexity & 1.27 & 1.51 & $0.41 *$ & 1.47 & 1.51 \\
\hline
\end{tabular}

813 
815 List of figures

816

817 Fig. 1. Demographic data of the respondents

818

819 Fig. 2. Research and analytic process

820

821 Fig. 3. SWOT Results

822 